\title{
Effect of Kinesthetic Perception, Eye-Hand Coordination, and Motivation on Lay Up Shoot
}

\author{
Gilang Ramadan ${ }^{1}$, Ardin Abdul Gani ${ }^{2}$, Arief Ibnu Haryanto ${ }^{3}$, Giofandi Samin ${ }^{4}$, Iwan \\ Fataha $^{5}$, Sulasikin Sahdi Kadir ${ }^{6}$ \\ Deparrtement Sport Science, Universitas Muhammadiyah Gorontalo, JI. Prof. Dr. H. Mansoer \\ Pateda, Telaga Biru, Gorontalo 96181, Indonesia \\ Email: gilang.ramadan@upmk.ac.id ${ }^{1}$, ardinabdgani@gmail.com ${ }^{2}$, ariefibnu67@gmail.com ${ }^{3}$, \\ giofandy.samin@gmail.com ${ }^{4}$, iwanfataha12@gmail.com ${ }^{5}$, sulasikinkadir@gmail.com ${ }^{6}$
}

\begin{abstract}
The purpose of this study was to determine whether there was a direct or indirect influence between kinesthetic perception, hand-eye coordination, and motivation for the shoot lay-up. The research method used in this study is Path Analysis to look for effects or relationships that affect variables. The subjects used in this study were Kuningan basketball athletes with 35 athletes. The results of this study show 1). There is a positive influence between kinesthetic perception (X1) on lay-up shoot skills $(\mathrm{Y})$ in basketball athletes, 2) There is a positive influence between hand-eye coordination ( $X 2)$ on a shoot $(Y)$ lay-up skills in basketball athletes, 3 ) There is a positive influence between motivation (X3) on the skill speed of the lay-up shoot (Y) in basketball athletes, 4) There is a positive influence between kinesthetic perception (X1) on motivation (X3) on basketball athletes, 5) There is effect positive between hand-eye coordination (X2) to motivation (X3) in basketball athletes, 6) There is a positive influence between kinesthetic perception (X1) on shoot shoot-up skills (Y) through motivation (X3) in basketball athletes and 7 ) There is a positive influence of handeye coordination (X2) on a shoot $(\mathrm{Y})$ through motivation (X3) lay-up skills in basketball athletes.
\end{abstract}

Keyword: perception, kinesthetic, coordination, motivation, shoot lay-up

(C) 2021 Gilang Ramadan, Ardin Abdul Gani, Arief Ibnu Haryanto, Giofandi Samin, Iwan Fataha, Sulasikin Sahdi Kadir Under the license CC BY-SA 4.0

\section{INTRODUCTION}

In the current era of development, people are starting to realize the importance of sports, both as recreational sports, achievement sports, and educational sports. With an increasing public understanding of the importance of sports development, marks based on educational sports and recreational sports gradually begin to move towards achievement sports. One of them is the development of the basketball game, which is starting to get attention in the public's eyes in general. The public's 
interest in this sport is increasing every year; this can be reflected in the consistently held championships to invite many spectators.

If we look at it, the basketball game is undoubtedly straightforward to do. In doing the basic techniques, the lay-up shoot is undoubtedly not as easy as it seems; there are so many components to becoming a perfect and beautiful movement pattern. Success in an appearance, especially in carrying out the basic techniques of someone who will do it, will very often depend on how much he can detect, feel and use the information he receives, the information he gets, both information that comes from outside (exteroceptive) and from inside (proprioceptive). Perception comes from the Latin perception, perception, which means action organize, recognize, and interpret sensory information to provide an overview and understanding of the environment.

Perception includes all signals in the nervous system resulting from physical or chemical stimulation of the sensory organs. Thus, the statement implies an understanding that kinesthetic perception refers to the body's ability to perceive or feel body movements so that it is not uncommon for kinesthetic perception to be called kinesthetic sense, which means a function of the organs of the body that is closely related to the position or position of the body. Body move. Success in performance depends on how effectively the performer detects, perceives, and uses appropriate sensory information.

Kinesthetic perception is a stimulus to a person's body or body parts that move simultaneously due to the stimulation of the senses (Arga Baskoro, 2016). So that one's feelings can give an idea of the position of the body or body parts to move further because one's five senses can control movements more accurately (Arga Baskoro, 2016). This implies that the human body can feel and hold the position of its body so that it can control movements or determine the amount of muscle work that will be carried out consciously so that the activities that will be produced are full of calculations, not only being able to do it in a specific time but eventually becoming motion automation.

Playing basketball relies on excellent physical strength in playing basketball because the movement or skill involved involves several elements, which are then assembled into a complex movement pattern. The role of eye-hand coordination in playing basketball is vital in supporting shooting skills. Because the better eye-hand 
coordination an athlete has, the better it will be when the athlete makes an accurate under basketball shot. Coordination can integrate various movement patterns towards an effective movement pattern (Sugiyanto \& Kristiiyanto, 1998).

So we can conclude that eye-hand coordination is a person's ability to integrate movement abilities between the eyes when receiving stimuli with hand movements. If these two patterns are made into one action, it will produce a coordinated, effective, and efficient movement pattern. Thus coordinated motion is a motion that is interconnected in its function so that eye-hand coordination is a motion that is a harmonious combination of balance timing and muscle coordination. Timing is a regulation of rhythm in a movement, which can be manifested in a timely contraction of a group of muscles to produce fast, sequential action.

While balance has an influential center of gravity in the plane of support and a vestibular function supported by the eye. (Suharno, 1993) the use of coordination and coordinating various movements well is also for 1) Efficiency and effectiveness of the energy needed in motion. 2) Can minimize the occurrence of injuries in various complex activities. 3) Can master several moves with high technique and will be easier if someone practices by having good coordination. 4) Preparing mentally in multiple situations in the play. So that eye-hand coordination has a massive role in achieving the desired results.

Motivation in carrying out sports activities is both extrinsic and intrinsic; motives are essential in sport, and sports psychologists can work with both extrinsic and intrinsic reasons to improve the performance of the individual (Jarvis, 2006). From this opinion, it can be concluded that motivation is a willingness that arises from within a person to work or practice harder; this is because he is driven by something. In this case, it is the motivation to train basketball athletes to practice more than usual.

One form of encouragement carried out by individuals in achieving a goal and activity is called a solid motivational basis for training. Motivation is the excellent power of internal or external that encourages a person to perform specific predetermined goals. With a psychological approach, it is expected that athletes in every appearance can show strong motivation to play their best to win matches.

Motivation is related to a goal; for example, a basketball player diligently trains tirelessly because he hopes to win in the match he will do. Thus, motivation affects 
the activity; in connection with this, there are three functions of reason, namely: (1) Encouraging people to act, (2) Determining the direction of action, (3) Selecting actions. In other words, motivation exists within a person and is inseparable in daily activities; even someone will really need a reason in carrying out activities such as sports, work, and even living (Ramadan \& Ningrum, 2019).

Every coach and player understands the role of kinesthetic perception in increasing the athlete's understanding in learning a complex movement to assess whether the activity is appropriate or still has shortcomings. Likewise, with eye-hand coordination and motivation, the better the coordination of an athlete, the better he or she can perform complex movements, and good reason will be able to bring an athlete to perform better. However, awareness of these three variables is not accompanied by how much these three variables influence the individual athlete's ability in the basic lay-up shoot technique.

About previous studies, there has been no research that has the similarity of each research variable explicitly. However, several previous studies have similarities with each of the variables in this study, such as the effect of the exercise approach and eye-hand coordination on the shooting accuracy of extracurricular basketball participants (Hermawan \& Rachman, 2018), then the Contribution of Leg Muscle Power, Kinesthetic Perception and Eye Coordination Hand Against the Success of the Basketball Jump Shoot (Rosmi, 2016).

According to researchers, an athlete needs to have good kinesthetic perception skills to learn complex movements quickly. But even an athlete must be able to have good coordination and motivation in terms of achievement. Therefore, to get an accurate picture of how the relationship between variables and how each variable affects each other, researchers are very interested in exploring this problem, especially when viewed from previous research there has been no research that has the same variables and research methods so that this will create an update of the initial analysis, for the sport itself.

\section{METHODS}

The research method used in this study is a quantitative approach, a survey method with measurement and test techniques. In contrast, the analysis technique uses a path analysis approach, which is a technique for analyzing causal 
relationships that occur in multiple regression if the independent variable affects the dependent variable or not. Only directly but also indirectly.

The subjects used in this study were 35 basketball athletes in the Kuningan area. The tests were given to determine the effect of each variable, so the sample was given four tests to assess the impact of each variable. The instrument is used to determine how much influence is generated on the lay-up shoot.

First, the instrument used for kinesthetic perception is the perception distance jump test (Johnson, BL, \& Nelson, 1986), while the test instrument for eye-hand coordination uses a tennis ball catch (Nurhasan, 2000) for The motivation for the test was given with a questionnaire that the researcher had made and for the lay-up shoot test using the lay-up shoot ability test (Nurhasan, 2000). each test is carried out in stages to determine the ability of the lay-up shoot.

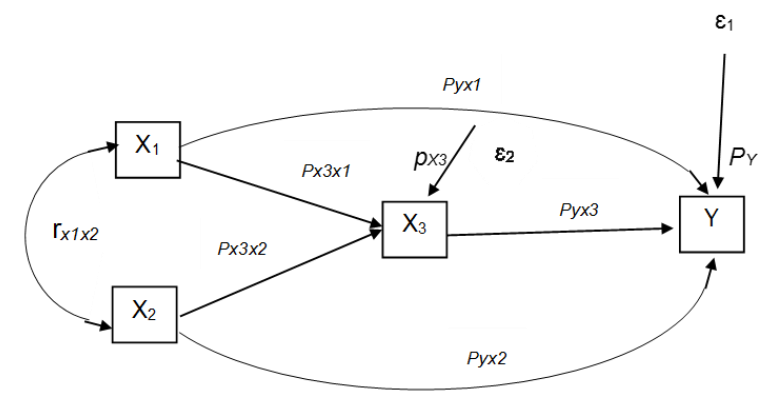

Figure 1 The relationship of the structure of $X 1, X 2$ and $X 3$ to $Y$ Source: Design (Ramadan \& Juniarti, 2020)

Information

X1 : Kinesthetic Perception

$\mathrm{X} 2$ : Eye and Hand Coordination

X3 : Motivation

Y : lay-up shoot

More specifically, this study aims to determine whether there is direct and indirect influence and how much impact on:

1. The immediate effect of kinesthetic perception on the lay-up shoot results.

2. The immediate effect of hand-eye coordination on the lay-up shoot results.

3. The immediate effect of motivation on the results of the lay-up shoot.

4. The direct effect of kinesthetic perception on motivation.

5. The direct effect of eye-hand coordination on motivation. 
6. The indirect influence of kinesthetic perception on the lay-up shoot results through motivation.

7. The indirect effect of eye-hand coordination on the lay-up shoot results through motivation.

After analyzing the causal structural model, the results obtained are used to test hypotheses and to measure the percentage of direct or indirect influence between variables. The proposed theory will be drawn by calculating the path coefficients and significance for each path studied.

\section{RESULTS AND DISCUSSION}

Since the data processing in this study uses statistical tests with path analysis techniques, it is necessary to test requirements analysis so that the results can be used to conclude. In this study, the test requirement referred to is the normality test.

To see whether the data obtained from each research variable were average or not, a normality test was performed using the Liliefors test. If the result of the highest Account (LO) from the group of variables studied is smaller than the $L$ table (Lt) in the list, the data is usually distributed.

While what is meant by Account (LO) is the difference between the most significant absolute price between the raw data opportunities and the raw data proportions. For more details, the results of calculating the normality of the variables studied using the Liliefors test at a significance level of $a=0.05$. This is illustrated in table 1 .

Table 1 Liliefors test

\begin{tabular}{lccc}
\hline No & Normality Test & Lo & Lt \\
\hline 1. & X1 normality test & 0,2346 & 0,1478 \\
2. & X2 normality test & 0,1351 & 0,1478 \\
3. & X3 normality test & 0,1874 & 0,1478 \\
4. & Y normality test & 0,1930 & 0,1478 \\
\hline
\end{tabular}

Furthermore, after going through the normality test of the data with the Liliefors test followed by the homogeneity test, this is used to determine whether the population variance is the same or not. This test is carried out as a prerequisite in the analysis, namely for researchers who use more than one sample group, which is generally used to prove comparative hypotheses. The underlying assumption in the study of variance is that the contentions of the population are the same. As a test 
criterion, if the significance value is more than 0.05 , it can be said that the conflicts of two or more data groups are the same.

Table 2 Homogeneous test

\begin{tabular}{llcc}
\hline No & \multicolumn{1}{c}{ Homogeneous Test } & Distribution & $\mathrm{F}_{\text {Table }}$ \\
\hline 1. & X1 homogeneity test against $Y$ & 0,967 & 1,77 \\
2. & X2 homogeneity test against $Y$ & 0,897 & 1,77 \\
3. & X3 homogeneity test against $Y$ & 0,937 & 1,77 \\
4. & X1 homogeneity test against X3 & 0,966 & 1,77 \\
5. & X2 homogeneity test against X3 & 0,966 & 1,77 \\
6. & Test the homogeneity of X1 against Y through X3 & 1,4237 & 1,77 \\
7. & Test the homogeneity of X2 against Y through X3 & 1,3986 & 1,77 \\
\hline
\end{tabular}

From the data above, we can conclude that the homogeneity test carried out by all of the tested data turned out to be homogeneous. The data will be continued for regression analysis.

Regression test analysis was conducted to test the relationship between variables, including fulfilling the requirements that these variables must have a linear relationship and the significance of the regression. In addition, it is also used to determine how big the correlation of the variables that have a causal relationship as the basis for calculating path analysis. For linearity requirements, if Fount $<F$ table. Meanwhile, to meet the significance of the regression if Fcount $>F$ table. The correlation coefficient value is a calculation number that states the level of strength of the relationship. The power of the correlation has an acceptable level of significance if $t$ count $>t$ table.

Table 3 Regression Test Analysis

\begin{tabular}{lll}
\hline No & \multicolumn{1}{c}{ Regression Test Analysis } & Distribution \\
\hline 1. & $X 1$ against $Y$ & Normal \\
2. & $X 2$ against $Y$ & Normal \\
3. $X 3$ against $Y$ & Normal \\
4. $X 1$ against $X 3$ & Normal \\
5. & $X 2$ against $X 3$ & Normal \\
6. $X 1$ against $Y$ through $X 3$ & Normal \\
7. $X 2$ against $Y$ through $X 3$ & Normal \\
\hline
\end{tabular}

Based on the calculation results of the structural path analysis, it provides objective information as follows:

1. Model-1 contribution results 
2. Some direct and indirect effects (through $\mathrm{X} 3$ ) and the total influence on the impact of Kinesthetic Perception (X1), Eye-hand Coordination (X2), and motivation (X3) on Lay-up Shoot skills (Y) are described as follows:

3. The direct effect of variable $X 1$ on $Y=0.659$ Indirect effect of variable $X 1$ on $Y$ through X3 $=0.659(0.625+0.764)=0.915$.

The total effect of $\mathrm{X} 1$ on $\mathrm{Y}=0.915$.

1. The direct effect of variable $X 2$ on $Y=0.621$ Indirect effect of variable $X 2$ on $Y$ through $\mathrm{X} 3=0.621(0.782+0.764)=0.960$.

The total effect of $\mathrm{X} 1$ on $\mathrm{Y}=0,960$.

1. The contribution of kinesthetic perception $(X 1)$, which directly affects shoot lay-up skills $(Y)$, is $0.6592=0.4342$ or $43.42 \%$.

2. The contribution of eye-hand coordination (X2) directly affects shoot lay-up skills $(\mathrm{Y})$ is $0.6212=0.3857$ or $38.57 \%$.

3. The contribution of motivation (X3) which directly affects shoot lay-up skills (Y) is $0.7642=0.5837$ or $58.37 \%$.

4. Contribution of kinesthetic perception (X1), eye-hand coordination (X2) and motivation $(X 3)$ simultaneously which directly affects shoot lay-up skills $(Y)$ is R2square $=0.638=63.8 \%$. The rest is $0.362=36.2 \%$.

5. Model-2 . contribution result

6. The contribution of kinesthetic perception (X1), which directly affects shoot lay-up skills (X3), is $0.6252=0.3906$ or $39.06 \%$.

7. The contribution of eye-hand coordination (X2), which directly affects shoot lay-up skills (X3), is $0.7822=0.6115$ or $61.15 \%$.

8. The simultaneous contribution of kinesthetic perception (X1) and eye-hand coordination (X2) which directly affects shoot lay-up skills (X3) is R2square = $0.675=67.5 \%$. The remaining $0.325=32.5 \%$.

Table 4 Summary of the decomposition of path coefficients, direct and indirect effects, the total impact of kinesthetic perception (X1), eye-hand coordination (X2), and motivation (X3) shoot lay-up skills

\begin{tabular}{lcccc} 
& \multicolumn{3}{c}{ Causal Influence } & Residue \\
Variable Effect & & Indirect & $\begin{array}{c}\varepsilon_{1} \text { and } \\
\varepsilon_{2}\end{array}$ & Total \\
& Directly & Through & & \\
\hline $\mathrm{X}_{1}$ against $\mathrm{Y}$ & 0,659 & - & - & 0,659
\end{tabular}




\begin{tabular}{lcccc} 
& - & $0,659(0,625+0,764)$ & - & 0,915 \\
$X_{2}$ against $Y$ & 0,621 & - & - & 0,621 \\
$X_{3}$ against $Y$ & - & $0,621(0,782+0,764)$ & - & 0,960 \\
$X_{1}, X_{2}, X_{3}$ against $Y$ & 0,764 & - & - & 0,764 \\
$X_{1}$ against $X_{3}$ & 0,638 & - & 0,362 & 1,00 \\
$X_{2}$ against $X_{3}$ & 0,625 & - & - & 0,625 \\
$X_{1}, X_{2}$ against $X_{3}$ & 0,782 & - & - & 0,782 \\
\hline
\end{tabular}

Based on the test results of all hypotheses that have been carried out in the hypothesis testing section, it can be stated that:

First, the hypothesis that there is a significant effect of kinesthetic perception and hand-eye coordination on motivation after testing the hypothesis is proven jointly and individually to affect shoot lay-up skills significantly. Structural equations from path analysis results from kinesthetic perception and eye-hand coordination on motivation $X 3=0,030 X 1+0,003 X 2+0,325 \varepsilon 1$. The magnitude of the kinesthetic perception variable and eye-hand coordination together to motivation is $67.50 \%$, while the remaining $32.50 \%$ is the influence of other variables apart from the kinesthetic perception variable and eye-hand coordination. Other variables that can influence motivation include internal factors, including the athlete's disposition, past experiences, aspirations, and expectations. Meanwhile, external factors include available facilities, infrastructure, training programs, and the environment.

The direct contribution of the kinesthetic perception variable (X1) to motivation (X3) is $0.6252 \times 100 \%=39.06 \%$. While the eye-hand coordination variable (X2) has a direct contribution of $0.7822 \times 100 \%=61.15 \%$. The correlation between kinesthetic perception and eye-hand coordination on motivation is $(0.625 \times 0.782 \times 0.675) \times$ $100 \%=32.99 \%$. The total influence of kinesthetic perception either directly or indirectly on motivation is $39.06 \%+32.99 \%=72.05 \%$. While the reaction speed contributes directly or indirectly to the overall motivation of $61.15 \%+32.99 \%=$ $94.14 \%$. These findings indicate that to increase motivation, basketball athletes must have an excellent kinesthetic perception, and eye-hand coordination contributes $67.50 \%$ to increase motivation.

Second, the hypothesis is that there is a significant effect of kinesthetic perception, hand-eye coordination, and motivation on lay-up shoot skills after jointly testing the hypothesis is substantial and when individual testing is also substantial. 
Based on the results of testing the hypothesis jointly and individually, it turns out that kinesthetic perception, eye-hand coordination, and motivation have a significant effect on shoot lay-up skills. The structural equation from the path analysis results from kinesthetic perception, hand-eye coordination and motivation to the results of the 100 meter short distance running speed is as follows: $Y=0,020 \mathrm{X} 1+$ $0,031 \times 2+0,004 \times 3+0,362 \varepsilon 1$

The magnitude of the contribution of the kinesthetic perception variable, handeye coordination, and motivation together to the lay-up shoot skill is $63.80 \%$. In comparison, the remaining $36.20 \%$ is the influence of other variables apart from the kinesthetic perception variable, eye-hand coordination. And motivation. Other variables that can affect lay-up shoot skills include implementing lay-up shoots effectively and efficiently according to initial attitude, speed, body position, leg movements, arm movements, coordination, and finish movements.

The contribution of the kinesthetic perception variable $(X 1)$ to the lay-up shoot skill (Y) directly is $0.6592 \times 100 \%=43.42 \%$. The eye-hand coordination variable $(\mathrm{X} 2)$ has a direct contribution of $0.6212 \times 100 \%=38.57 \%$. While the motivation variable (X3) has a direct contribution of $0.7642 \times 100 \%=58.37 \%$. The effect between $d$ kinesthetic perception, hand eye coordination and motivation which correlates to shoot lay-up skills is $(0.659 \times 0.621 \times 0.638) \times 100 \%=26.10 \%$. The total influence of kinesthetic perception either directly or indirectly on lay-up shoot skills is $43.42 \%+$ $26.10 \%=69.52 \%$. Eye-hand coordination directly or indirectly on lay-up shoot skills as a whole is $38.57 \%+26.10 \%=64.67 \%$. While the motivation to contribute directly or indirectly to the lay-up shoot skills as a whole is $53.37 \%+26.10 \%=79.47 \%$.

These findings indicate that to improve shoot lay-up skills. Every basketball player must have an excellent kinesthetic perception, eye-hand coordination, and motivation, all of which have a contribution of $63.80 \%$ to be able to improve shoot lay-up skills.

\section{CONCLUSION}

Based on the data analysis and statistical calculations described in the previous review from the discussion of research results conducted on basketball athletes, Kab. Kuningan, then at this point, the following conclusions are put forward. 
Conclusions were drawn based on research findings with exogenous variables consisting of kinesthetic perception (X1), hand-eye coordination (X2), and motivation (X3). The endogenous variable consists of shoot lay-up skills (Y).

1. There is a positive influence between kinesthetic perception (X1) on lay-up shoot skills $(Y)$ in basketball athletes.

2. There is a positive influence between eye-hand coordination (X2) on lay-up shoot skills $(Y)$ in basketball athletes.

3. There is a positive influence between motivation (X3) on the speed of shoot lay-up skills $(\mathrm{Y})$ in basketball athletes.

4. There is a positive influence between kinesthetic perception (X1) on motivation (X3) in basketball athletes.

5. There is a positive influence between eye-hand coordination (X2) on motivation (X3) in basketball athletes.

6. There is a positive influence between kinesthetic perception (X1) on shoot layup skills $(\mathrm{Y})$ through motivation (X3) in basketball athletes.

7. There is a positive effect of eye-hand coordination (X2) on shoot lay-up skills (Y) through motivation (X3) in basketball athletes.

Thus, lay-up shoot skills can be improved by increasing kinesthetic perception, eye-hand coordination, and motivation.

By paying attention to the description above, it is clear that knowledge of the status of an athlete's physical and mental condition and which components of physical condition are more supportive of all sports because it is one of the critical factors for a coach or sports coach of achievement who wants to succeed in coaching towards the athlete.

Therefore, a coach or coach of sports achievements must know which components of physical and mental condition and which techniques contribute more dominantly than the other components to develop an efficient and adequate physical exercise program. They will be more careful in estimating the results obtained. Athletes will be able to achieve when participating in competitions, especially basketball, and will be able to accurately evaluate the effects of achievements that have been achieved by athletes, including in coaching the athlete's physical condition. 


\section{REFERENCES}

Alexander, M. J. L. (2016). The Effectiveness of the Shotloc Training Tool on Basketball Free Throw Performance and Technique. International Journal of

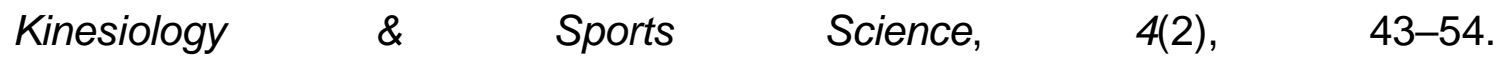
https://doi.org/10.7575/aiac.ijkss.v.4n.2p.43

Arga Baskoro, D. (2016). Hubungan Kekuatan Otot lengan, Vo2 Max dan Persepso Kinestetik Terhadap Akurasi Tembakan Jarak 50 Meter. Journal of Physical Education, Sport, Health and Recreations, 5(3), 130-133.

Bompa, T. O., \& Buzzichelli, C. (2018). Periodization: Theory and methology of Training. Human Kinetics Publishers.

Hermawan, D. A., \& Rachman, H. A. (2018). Pengaruh pendekatan latihan dan koordinasi mata tangan terhadap ketepatan shooting peserta ekstrakurikuler basket. Jurnal Keolahragaan, 6(2), 100-109. https://doi.org/10.21831/jk.v0i0.20349

Husdarta, H. J. S. (2011). Manajemen Pendidikan Jasmani. Bandung: Alfabeta.

Jarvis, M. (2006). Sport Psychology A Student's Handbook. New York: Routledge.

Johnson, B. L., \& Nelson, J. K. (1986). Practical measurements for evaluation in physical education. Minnesota: Burgess Pub.

Nurhasan. (2000). Tes dan pengukuran pendidikan olahraga. Jakarta: Kurunika.

Ramadan, G., \& Iskandar, D. (2018). Pengaruh Gaya Mengajar dan Motivasi Belajar Terhadap Hasil Belajar Lay Up Shoot. Jurnal Pendidikan Edutama. https://doi.org/10.30734/jpe.v5i1.133

Ramadan, G., \& Ningrum, D. A. (2019). Pengaruh Kemampuan Motorik, Imagery dan Motivasi Terhadap Hasil Belajar Lay-up Shoot. JUARA : Jurnal Olahraga, 4(1), 36-42. https://doi.org/10.33222/juara.v4i1.399

Rosmi, Y. F. (2016). Kontribusi Power Otot Tungkai, Persepsi Kinestetik dan Koordinasi Mata Tangan Terhadap Keberhasilan Tembakan Lompat (Jump Shoot) Bolabasket. Jurnal Pendidikan Buana, 12(22), 135-160.

Sugiyanto, Sugiyanto \& Kristiayanto, A. (1998). Belajar Gerak II. Surakarta: UNS 


\section{Press.}

Sugiyono. (2010). Metode penelitian kuantitatif kualitatif dan $R \& D$. Bandung: Alfabeta.

Suharno, suharno. (1993). Metodologi Pelatihan. Yogyakarta: IKIP Yogyakarta.

Wisel, H. (2011). BasketBall: Steps to Succes. Human Kinetics Publishers. 